\title{
New treatments for influenza
}

\author{
Sailen Barik ${ }^{1,2}$
}

\begin{abstract}
Influenza has a long history of causing morbidity and mortality in the human population through routine seasonal spread and global pandemics. The high mutation rate of the RNA genome of the influenza virus, combined with assortment of its multiple genomic segments, promote antigenic diversity and new subtypes, allowing the virus to evade vaccines and become resistant to antiviral drugs. There is thus a continuing need for new anti-influenza therapy using novel targets and creative strategies. In this review, we summarize prospective future therapeutic regimens based on recent molecular and genomic discoveries.

Keywords: Cathelicidin, defensin, influenza, hemagglutinin, neuraminidase, NSAID, oseltamivir, siRNA, zanamivir
\end{abstract}

\section{Review}

\section{Background}

Influenza, commonly known as 'flu', is a respiratory infection contracted by $5 \%$ to $50 \%$ of the US population annually, roughly 200,000 of whom are hospitalized and 25,000 die (with significant year-to-year variation) [1-4]. Clinically, influenza presents itself with high fever, chills, sore throat, headache, runny or stuffy nose, weakness, muscle pain and sometimes diarrhea (vomiting in children). Although more severe than common cold, influenza is generally a self-limiting disease in healthy adults that lasts about a week, but cough and lethargy may continue for some time. In the population, influenza follows the general pattern that now appears to characterize essentially all respiratory infections, in that it can be particularly hazardous to individuals with poor immunity such as children and the elderly, and those with pulmonary, cardiovascular or other complications. Pneumonia, either a direct result of the virus infection in the lung, or through

\footnotetext{
Correspondence: s.barik@csuohio.edu

${ }^{1}$ Center for Gene Regulation in Health and Disease, Cleveland State

University, 2351 Euclid Avenue, Cleveland, Ohio 44115, USA

Full list of author information is available at the end of the article
}

secondary bacterial infections shortly after the viral episode, is also common in influenza, particularly among adults [2]. Secondary bacterial pneumonia often complicates influenza and in fact played a significant role in the morbidity and mortality associated with all past pandemics, including the most recent 'swine flu' of 2009 [2,5]. Prompt antibiotic treatment is required to reduce mortality. Relatively rare complications of influenza include myositis (muscle inflammation), myocarditis and pericarditis (affecting the heart), Reye's syndrome and possibly Guillain-Barré syndrome. Although the primary target and clinically relevant tissue in influenza virus infection is the respiratory epithelium [2], facultative infection of other organs, such as the cardiac or skeletal muscle, is possible and has occasionally been documented in cell culture and experimental animal infections [6-10]. The predominant mode of natural transmission of the influenza virus is by aerosols, generated by coughing or sneezing; however, it is also transmitted by nasal secretions and contact with contaminated surfaces. While all respiratory viruses, including influenza, use the nose as the common entry channel, they can also enter through the eye, likely via the tear duct, draining into the sinus and the airways [11]. The virus particles are inactivated by the ultraviolet rays in sunlight and common disinfectants such as soap. Thus, frequent hand washing is recommended during influenza epidemics to minimize virus spread.

The influenza viruses are RNA viruses of the Orthomyxoviridae family, in which the viral genome is divided into multiple segments [4]. For example, the total genome of influenza A, which is responsible for the vast majority of seasonal influenza in humans, consists of eight negative sense (anti-mRNA sense) RNA segments. Together, they code for 10 viral proteins: three subunits of viral RNAdependent RNA polymerase (RdRP) (PA, PB1, PB2); major surface glycoproteins, hemagglutinin (HA) and neuraminidase (NA); nucleocapsid protein (NP); matrix proteins (M1, M2); and two nonstructural proteins, NS1 and NS2 [4]. In some strains of animal influenza virus, the PB1 gene also produces a small, 87 -residue protein, named PB1-F2, by internal translational initiation of an alternate reading frame; this protein shows a predominantly mitochondrial localization and promotes apoptosis in immune 
cells, likely aiding viral transmission [12]. The influenza viral genomic RNA is wrapped with the NP protein and the resultant ribonucleoprotein (NP-RNA) is transcribed by the viral RdRP to produce viral mRNAs that serve as templates for viral protein synthesis. The NP-RNA complex is encapsidated in a lipid bilayer, studded with the HA and NA glycoproteins and traversed by the M2 protein (Figure 1), which is an ion (proton) channel [4]. The nonstructural proteins are so named because they are not packaged into mature virus particles; however, they play essential roles in the infected cell. NS1 interacts with a large number of host proteins including several members of the innate immune pathways [13-20], and hence contributes to virus growth, pathogenicity and tropism [21-24]. NS2, also called nuclear export protein, mediates nucleusto-cytoplasmic export of the viral RNA by acting as an adaptor between viral ribonucleoprotein complexes and the nuclear export machinery of the cell.

Influenza viruses are divided into subtypes $\mathrm{A}, \mathrm{B}$ and $\mathrm{C}$, based on genetic and antigenic differences in their HA and NA surface glycoproteins [4,25]. Seasonal human influenza is caused by both types $A$ and $B$, whereas $C$ is

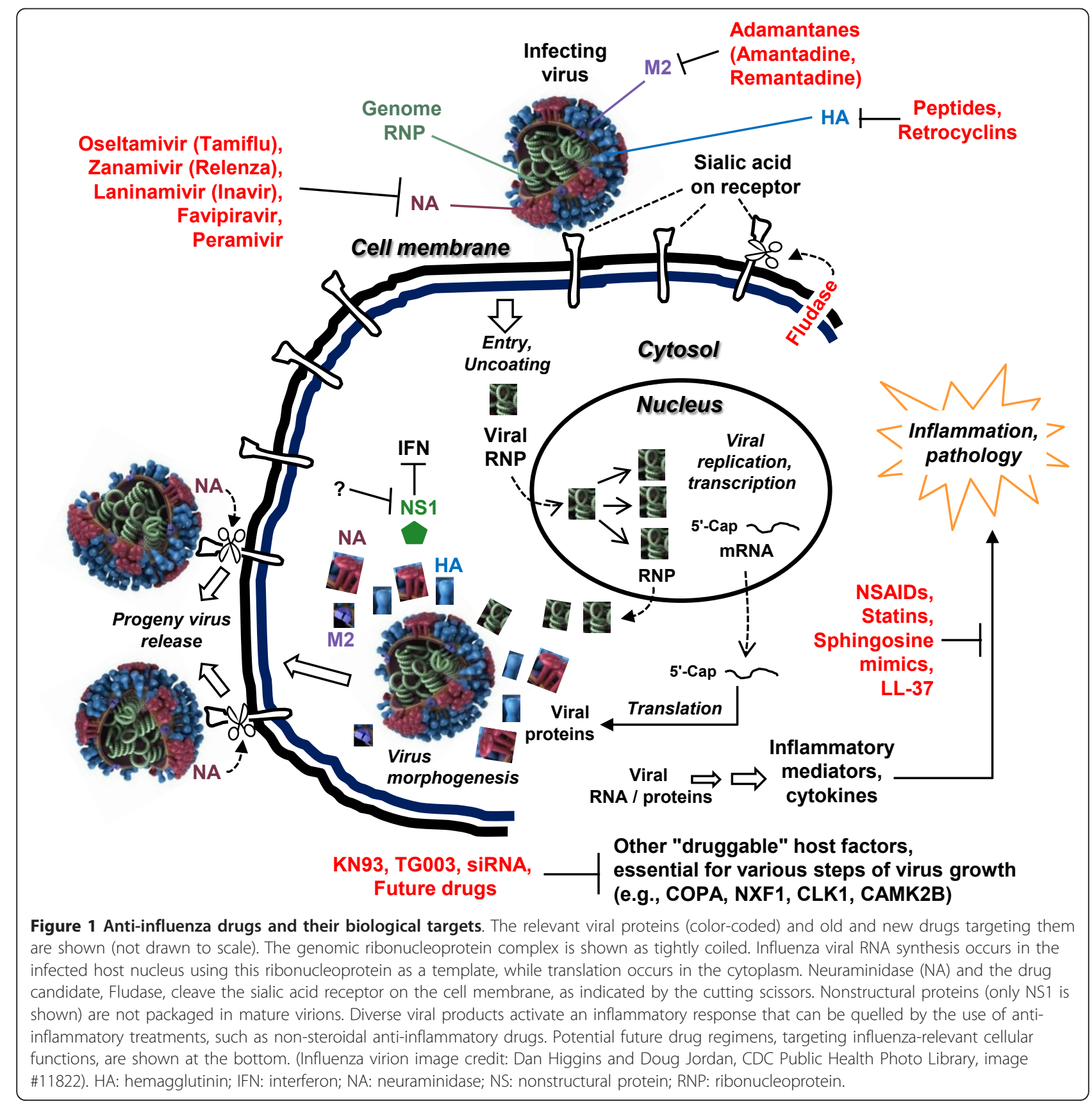


rare and only causes a mild disease in children $[3,4]$. The type A viruses also naturally infect a variety of nonhuman species, including birds, pigs, horses, cats, dogs, seals and whales [3,25-28]. There are 16 known HA (H1 to H16) and 9 NA (N1 to N9) subtypes in influenza A $[4,25]$, leading to the current $\mathrm{HxNy}$ nomenclature. Routine human infections of seasonal influenza are mainly due to H1N1, H1N2 and influenza B; however, H3N2 is gradually becoming more abundant [29]. In 2011, a new variant of $\mathrm{H} 3 \mathrm{~N} 2$, sometimes referred to as H3N2v, was found in a dozen patients in the US. The more deadly pandemics and epidemics have been caused by various mutant variants and subtype combinations. The 1918 'Spanish flu' and the 2009 'swine flu' were both caused by H1N1 type viruses, the 1957 'Asian flu' was caused by an H2N2, the 1968 'Hong Kong flu' by H3N2 and the 2004 'bird flu' by H5N1. Antigenic drift within a specific HA or NA number is also common (see 'Difficulties of prevention and treatment of influenza' below).

An interesting and clinically relevant aspect of pandemic and epidemic influenza that sets it apart from seasonal influenza is the induction of the so-called cytokine storm, consisting of interleukin-6, tumor necrosis factor $\alpha$ and interferon $-\gamma$. Together, these proinflammatory cytokines cause systemic inflammatory response syndrome, leading to multiorgan failure that includes airways destruction, vascular endothelial damage and plasma leakage [30-35].

\section{Difficulties of prevention and treatment of influenza}

There are a number of difficulties in influenza treatment and prevention, contributing to the constant threat of the disease. These are summarized below. A prior understanding of these factors is clearly important in strategizing new treatments.

\section{Rapid mutability}

Like all RNA genomes, the influenza virus genome lacks a proofreading mechanism and thus mutates relatively frequently. Mutations may offer the virus various selective advantages, such as resistance to existing vaccines and antiviral drugs [36] - even small changes in the viral HA and NA antigen sequences, known as antigenic drift, may allow the virus to escape from the host's adaptive immunity [37]; increased infectivity and virulence; and greater horizontal spread (that is, one individual to another in the same species) and vertical spread (that is, crossing of the host species, such as from pig to man, generally due to a 'variant' virus). Larger diversity and more extensive changes can be rapidly generated by genetic reassortment, as described below.

\section{Genomic reassortment}

As the influenza genome is segmented (multiple pieces), new strains can quickly appear by reassortment in coinfection. Known as antigenic shift, this often leads to hybrid strains that are markedly different [25]. For example, co-infection by human and swine (pig) influenza viruses can generate reassortant viruses that will have genomic RNA segments from the two viral species [38]. Such a hybrid can cause a major epidemic because the human population will lack any natural immunity to it. It has been speculated that the 1918 influenza virus, which caused the largest influenza pandemic recorded in history, was caused by such a reassortant virus $[39,40]$. The 2009 Mexican swine influenza is likely a product of multiple assortments between swine, human and European avian-like strains $[41,42]$. Obviously, reassortment may result in a new combination of the HA and NA segments, thus changing the subtype name of virus as well.

\section{Vulnerable population groups}

Influenza can be particular deadly to specific groups in the population, such as the elderly and individuals with diabetes or immune deficiency (such as those with AIDS). In fact, people aged 65 years or older account for $90 \%$ of seasonal influenza-associated deaths, even though this group makes up only approximately $15 \%$ of the population [1,2]. Thus, this group is in the greatest need of prophylaxis or more intensive treatments against influenza but, unfortunately, they are also generally less tolerant to aggressive treatments.

The brief background presented above should make it clear that reliable prevention and treatment of influenza is a critical need in public health. In this review, we start by summarizing the various current and now-defunct treatments for influenza (amantadine, oseltamivir (Tamiflu), zanamivir (Relenza)), as there are lessons to learn from their success and failure. We then discuss and critically review the prospective future anti-influenza treatments that are at different stages of development (newer NA inhibitors, sialidase, defensins, cathelicidin, statins, siRNA and host proteins).

\section{Current and past treatments}

\section{M2 ion channel inhibitors: adamantanes}

The influenza viral M2 protein acts as an ion channel that allows proton translocation through the virion envelope (Figure 1). This leads to acidification of the viral core, its resultant dissociation and the release of the viral NP-RNA complex in the infected cell cytoplasm, which is essential for viral RdRP function and viral gene expression [4]. The M2 inhibitors are adamantanes, characterized by three condensed cyclohexane rings fused in the chair conformation. Two M2 inhibitors, amantadine and rimantadine, were widely used against influenza but are now largely discontinued and replaced by NA inhibitors [43]. As one would predict from the role of M2 in the viral life cycle, these drugs were effective only when administered soon after diagnosis [43]. Nonetheless, their efficacy is limited to influenza A only, since influenza B viruses lack M2. 
Moreover, essentially all influenza strains have now developed high resistance against both amantadine and rimantadine. This has been attributed to their easy over-thecounter availability in highly populated nations such as China and Russia, and their large-scale use in the poultry for protection against 'chicken flu'.

\section{Old neuraminidase inhibitors Oseltamivir (Tamiflu)}

The most popular influenza treatment regimen, developed nearly three decades after the M2 inhibitors, targets the viral NA. The NAs possess glycoside hydrolase activity that cleaves the glycosidic linkages of neuraminic acids. The influenza virus uses viral $\mathrm{HA}$, a virion surface protein, to bind to sialic acid groups (Figure 2) on cell surface glycoproteins (Figure 1) [45]. For the progeny virions to be released from the cell, the NA activity must cleave the sialic acid groups from the host glycoproteins, and this is essential for viral spread and reinfection (Figure 1). Thus, blocking the function of NA with specific inhibitors is an effective way to treat influenza.

The influenza NA is a classic example of rational drug design based on the crystal structure of NA $[46,47]$. Currently, two NA inhibitors are used in clinical practice: oseltamivir (Tamiflu; Roche/Genentech) and zanamivir (Relenza; GlaxoSmithKline) (Figure 2). The 2009 $\mathrm{H} 1 \mathrm{~N} 1$ pandemic witnessed record sales of both drugs, together exceeding US \$4 billion, partly due to stockpiles for fear of a forthcoming epidemic. Both drugs bind the catalytic pocket of NA and function as competitive inhibitors of NA activity.

Oseltamivir as a prodrug is sold in capsules containing $30 \mathrm{mg}, 45 \mathrm{mg}$ or $75 \mathrm{mg}$ oseltamivir phosphate and also as powder for oral suspension in water $(6 \mathrm{mg} / \mathrm{mL})$. For treatment of influenza, the recommended dose for adults is $75 \mathrm{mg}$, twice a day, for 5 days. The preventive (prophylactic) dose is usually $75 \mathrm{mg}$, once a day for at least 10 days, or for up to 6 weeks during a community influenza outbreak. Smaller doses are recommended for children, according to age and weight. Adverse drug reactions may include nausea, vomiting, diarrhea, abdominal pain, headache and neuropsychiatric events such as self-inflicted injury and delirium (Table 1) [36]. As with many drugs, such as the M2 inhibitors [43], oseltamivir may be less effective if used in late-stage influenza.

\section{Zanamivir (Relenza)}

Zanamivir is more effective than oseltamivir and is supplied for oral inhalation only [36]. It is sold as doublefoiled 'blisters' that release the drug in an inhaler when pierced by the user. Each blister contains a powder mixture of $5 \mathrm{mg}$ of zanamivir and $20 \mathrm{mg}$ of lactose (plus milk proteins). The recommended dose for treatment of influenza in adults and pediatric patients aged 7 years and older is $10 \mathrm{mg}$ twice daily (that is, two inhalations, one 5-mg blister per inhalation) for 5 days. For prevention of influenza (prophylaxis), the recommended dose in adults and pediatric patients 5 years and older is 10 mg once daily for 10 days, inhaled as above. Adverse drug reactions are rarer than with oseltamivir (Table 1). Resistance to oseltamivir and zanamivir: what they tell us Influenza virus mutants, resistant to either drug, have been characterized from cell culture as well as from patients $[43,48,49]$ and are particularly well-studied for oseltamivir. Interestingly, resistant mutations were found not only in the NA gene, but also in HA. It appeared that, at least in cell culture, two HA or an HA and NA mutation can act synergistically to increase resistance [53]. As expected, the NA mutations were in conserved catalytic (Arg152, Arg292) and structural (Glu119, Asp198, His274, Asn294) residues. A few common mutations were: R152K, R292K, E119V, D198N, H247Y (highly prevalent) and N294S [54]. Double mutations with synergistic oseltamivir resistance phenotype have been noted as well. This includes the E119V+I222V double mutant, isolated from an immunocompromised child infected with $\mathrm{H} 3 \mathrm{~N} 2$ virus, and $\mathrm{H} 247 \mathrm{Y}$ $+\mathrm{I} 222 \mathrm{~V}$, from patients infected with the $\mathrm{H} 1 \mathrm{~N} 1$ virus of the 2009 pandemic.

For future drug design and resistance expectation, it is important to learn that the effect of these mutations is dependent both on the NA subtype and the drug used $[55,56]$. Generally, catalytic site mutants exhibit drug resistance, but also show decreased NA activity, such that viral infectivity, pathogenicity and transmissibility are affected. By contrast, mutations of the structural residues exhibit drug resistance without a significant effect on NA functionality. Thus, in natural selection against these drugs, the structural mutations may be favored because they would retain viral fitness. Lastly, the HA mutations tend to map to regions associated with receptor binding of the $\mathrm{HA}$, apparently lowering the affinity of the HA for the cellular receptor, such that NA is no longer required for virus release.

Readers interested in the detailed dosage of the existing drugs (amantadine, rimantadine, oseltamivir and zanamivir) are encouraged to read the highly comprehensive treatise of the Advisory Committee on Immunization Practices from the National Center for Immunization and Respiratory Diseases, Center for Disease Control and Prevention, USA [57].

\section{New and prospective future treatments \\ New and future neuraminidase inhibitors}

Laninamivir Recently, a new NA inhibitor, laninamivir (Inavir; Daiichi-Sankyo and Biota; Figure 2), has been approved for use in Japan [50,51], and is currently being developed in the US. It is a highly promising and 
<smiles>CC(=O)N[C@H]1[C@@H]([O])CC(O)(C(=O)O)O[C@@H]1[C@@H](O)C[C@H](O)CO</smiles>

Sialic acid (NANA) (CID 439197)<smiles>CCOC(=O)C1=C[C@@H](OC(CC)CC)[C@H](NN)[C@H](N)C1</smiles>

Oseltamivir (Tamiflu) (CID 65028)<smiles>CC(=O)N[C@H]1[C@H](N=C(NN)NN)C=C(C(=O)O)O[C@]1([18OH])[C@H](O)[C@H](O)CO</smiles><smiles>NC(=O)c1nc(F)cnc1O</smiles>

Favipiravir (CID 492405)

Zanamivir (Relenza)

(CID 60855)<smiles>CCC(CC)[C@H](NC(C)=O)[C@@H]1[C@H](O)[C@@H](C(=O)OP)C[C@H]1N=C(NN)NN</smiles>

Peramivir (CID 151164)<smiles>[2H][C@@]1([C@H](OC)[C@H](O)CO)OC(C(=O)O)=C[C@H](N=C(NN)NN)[C@H]1NC(C)=O</smiles>

Laninamivir (CID 502272)<smiles>CC(C)c1c(C(=O)Nc2ccccc2)c(-c2ccccc2)c(-c2ccc(F)cc2)n1CC[C@@H](O)C[C@@H](O)CC(=O)O</smiles><smiles>C#CC(CCc1ccc(CCCCCCCC)cc1)(COC)COC</smiles><smiles>COc1ccc(S(=O)(=O)N(CCO)c2ccccc2CN(C)C/C=C/c2ccc(Cl)cc2)cc1</smiles><smiles>C/C=C\N=NNC(=O)c1ccccc1O</smiles>

Figure 2 Structure of selected class-representative anti-influenza drugs, old as well as prospective ones. The neuraminidase inhibitors, and $\mathrm{N}$-acetyl neuraminic acid that they mimic, are shown in the box. For all molecules, the PubChem compound numbers (CID\#) are written under each name. In FTY720, one of the two -OH groups is phosphorylated to yield the bioactive phosphate derivative (not shown). The structure of AAL-4 is similar (not shown), but it has only one -OH group instead of two, which is phosphorylated much faster. M2 inhibitors are not shown for lack of space and because they are largely discontinued due to viral resistance. All structures were obtained from the free PubChem Compound Database at National Center for Biotechnology Information (accessed June 15, 2012) [44]. NANA: N-acetyl neuraminic acid. 
Table 1 Old and new influenza drugs

\begin{tabular}{|c|c|c|c|}
\hline $\begin{array}{l}\text { Name (major } \\
\text { brand) }\end{array}$ & Effective against & Recommended dose & Use status; adverse drug reactions \\
\hline $\begin{array}{l}\text { Amantadine } \\
{[43]} \\
\text { (Symadine, } \\
\text { Symmetrel) [43] }\end{array}$ & Influenza A & $\begin{array}{l}\text { Capsule/tablet, syrup; } 100 \mathrm{mg} \\
\text { amantadine hydrochloride, twice a day. }\end{array}$ & $\begin{array}{l}\text { Mostly discontinued due to resistance; may be recalled in } \\
\text { future epidemics. }\end{array}$ \\
\hline $\begin{array}{l}\text { Oseltamivir } \\
\text { (Tamiflu) }[48,49]\end{array}$ & Influenza A, B & $\begin{array}{l}\text { Capsule ( } 30,45,75 \mathrm{mg}) \text { twice a day; } \\
\text { powder for suspension ( } 6 \mathrm{mg} / \mathrm{mL})\end{array}$ & $\begin{array}{l}\text { Currently in use. Transient nausea, vomiting, abdominal pain, } \\
\text { headache, neuropsychiatric episodes. }\end{array}$ \\
\hline $\begin{array}{l}\text { Zanamivir } \\
\text { (Relenza) [36] }\end{array}$ & Influenza A, B & Two inhalations (5 or $10 \mathrm{mg}$ each). & $\begin{array}{l}\text { Currently in use. Relatively rare adverse drug reactions include } \\
\text { nausea, diarrhea, respiratory problems, dizziness. }\end{array}$ \\
\hline $\begin{array}{l}\text { Laninamivir } \\
{[50,51]}\end{array}$ & $\begin{array}{l}\text { Influenza A, B (for } \\
\text { example, H1N1, H3N2) }\end{array}$ & Single inhalation (20 or $40 \mathrm{mg}$ ). & $\begin{array}{l}\text { Similar to oseltamivir. Approved in Japan, but not yet in the } \\
\text { US. }\end{array}$ \\
\hline Peramivir [52] & Similar to Laninamivir & $\begin{array}{l}\text { Intravenous } 600 \mathrm{mg} \text { once, or } 300 \mathrm{mg} \\
\text { twice, } 5 \text { to } 10 \text { days. }\end{array}$ & $\begin{array}{l}\text { Transient nausea, vomiting, and diarrhea (similar to } \\
\text { oseltamivir). Approved in Japan and Korea. }\end{array}$ \\
\hline
\end{tabular}

Some information was obtained from manufacturers' inserts and/or websites.

long-acting NA inhibitor that efficiently inhibits common oseltamivir-resistant viruses, including those with the H274Y substitution [58]. Co-crystal structure of laninamivir-NA has revealed that laninamivir-binding shares some of the same residues as oseltamivir and zanamivir [58]. Nonetheless, the three drugs differ in their pharmacokinetics [52]. Laninamivir is only available for inhalation, and a single inhalation has been shown to be as effective as repeated doses of oseltamivir or zanamivir [50], likely due to its long persistence in the lung. The single use regimen is expected to promote improved patient compliance and convenience [51].

Favipiravir The second new investigational drug against NA is T-705 (favipiravir; 6-fluoro-3-hydroxy-2-pyrazinecarboxamide; Figure 2) [59] that has shown antiviral activity against seasonal influenza viruses as well as oseltamivir-sensitive or -resistant highly pathogenic H5N1 viruses [60]. Moreover, its active form is a ribofuranosyl triphosphate derivative that mimics purines or purine nucleosides and inhibits the viral RdRP but does not inhibit human polymerases [59]. Thus, favipiravir shows excellent promise for the treatment of patients with the highly pathogenic H5N1 influenza. The National Institutes of Health of the US is currently conducting a Phase II, randomized, double-blind, placebo-controlled, multicenter (in 235 study locations) study evaluating the efficacy and safety of favipiravir in adult patients with uncomplicated influenza (ClinicalTrials.gov identifier NCT01068912; sponsor: FujiFilm Pharmaceuticals USA, Inc.). A 5-day regimen is being tested with low-dose (1000 mg favipiravir twice for 1 day, followed by $400 \mathrm{mg}$ favipiravir twice a day for 4 days) as well as high-dose favipiravir (1200 mg favipiravir twice for 1 day, followed by $800 \mathrm{mg}$ favipiravir twice a day for 4 days). The results are expected to be available in late 2012 or early 2013.

Peramivir The third new compound in the NA-inhibitor category is peramivir (Biocryst Pharmaceuticals; Figure 2).
It is the only intravenous (IV) option used for the treatment of certain hospitalized patients with known or suspected 2009 pandemic H1N1 influenza, but its approval by the US Food and Drug Administration expired soon after the pandemic. A phase III clinical trial of parenteral (IV) peramivir, conducted on 230 patients in 110 study locations and sponsored by the US Department of Health and Human Services, was recently completed (ClinicalTrials.gov identifier NCT00957996; sponsor: BioCryst Pharmaceuticals). It tested the safety and tolerability of peramivir administered either as a once-daily infusion of $600 \mathrm{mg}$ or a twice-daily infusion of $300 \mathrm{mg}$ to adult and adolescent patients hospitalized with confirmed or suspected influenza infection. Both dose regimens of IV peramivir were found to be safe and well-tolerated. Another phase III study of IV peramivir has also been initiated and continues at the time of this writing (ClinicalTrials.gov identifier NCT00958776; sponsor: BioCryst Pharmaceuticals). Because of its intravenous applicability, peramivir is particularly useful when a patient has developed resistance to oseltamivir and is unable to inhale zanamivir (for example, patients with asthma), the two major anti-influenza drugs. Peramivir is already being sold in Japan under the trade name Rapiacta, and in South Korea under the name Peramiflu.

The promise of such new generation NA inhibitors suggests that NA may continue to provide a rational target for newer inhibitors in the future, effective against viruses that will develop resistance to the older inhibitors [46].

\section{Hemagglutinin inhibitors \\ EB peptide}

In an interesting report [61], a 20-amino-acid peptide (RRKKAAVALLPAVLLALLAP), derived from the signal sequence of fibroblast growth factor 4, specifically bound to the influenza viral HA protein (Figure 1) and exhibited broad-spectrum antiviral activity against influenza viruses 
including H5N1. Named EB for Entry Blocker, the peptide was also protective when administered post-infection, suggesting that it prevented reinfection, which underscored its therapeutic potential.

\section{Peptide NDFRSKT}

In a complementary approach [62], a heptapeptide phage display library was biopanned against purified avian influenza virions of subtype H9N2. Multiple rounds of panning and antiviral screening led to the identification of the peptide NDFRSKT with strong antiviral properties. The peptide inhibited the hemagglutination activity of the viruses but not the NA and hemolytic activities. Further studies confirmed that the peptide directly interacted with the HA protein. The therapeutic status of the peptide remains unknown.

\section{Fludase, a neuraminidase mimic}

Fludase (DAS181) is a recombinant chimeric enzyme in which a fungal sialidase catalytic domain is fused to a cell surface-anchoring domain $[63,64]$. Enzymatically, it functions essentially like the viral NA and destroys the host cell surface sialic acid receptors of the virus (Figure 1). Thus, it differs from the NA inhibitors in two respects: it is a protein, not a small compound; and it targets the host cell rather than the virus itself. In preclinical studies, Fludase inhibited both human and avian lethal influenza viruses $[63,64]$. Fludase is designed and developed by NexBio (http://www.drugdevelopment-technology.com/ projects/fludase); however, its future development by the company remains uncertain.

\section{Anti-inflammatory drugs}

With the recognition that the body's hyperactive inflammatory response is a root cause of organismic and systemic damage in many pathological states, efforts at quelling inflammation have received pharmaceutical attention [65-67]. Notable direct and indirect anti-inflammatory regimens, tested in various infections, include corticosteroids, aspirin (a common non-steroidal anti-inflammatory drug), monoclonal antibodies, antagonists of cytokines and chemokines, statins and sphingosine analogs. They might be particularly helpful in pandemic events, which, as mentioned before, are characterized by exaggerated synthesis of proinflammatory cytokines, known as a cytokine storm [68]. Although anti-inflammatory drugs have produced mixed, and sometimes conflicting, results in patients with influenza, a few are worth mentioning here.

\section{Statins}

Statins inhibit cellular 3-hydroxy-3-methylglutaryl-coenzyme A (HMG-CoA reductase), an enzyme essential for cholesterol biosynthesis in the liver, and are extensively prescribed to treat hypercholesterolemia [69]. Statins are relatively safe with rare incidents of myositis, myopathy and neuropathy. Thanks to the generally accepted correlation of high serum cholesterol levels and predisposition to atherosclerosis, multiple statins are currently blockbuster pharmaceuticals that include: atorvastatin (Figure 2) (Lipitor by Pfizer), lovastatin (Mevacor by Merck \& Co.), and simvastatin (Zocor by Merck \& Co.), as well as generic varieties.

In relatively recent approaches, statins have been tested in influenza, based on the premise that they might reduce the mortality and morbidity caused by the cytokine storm $[30,65,66,70,71]$. However, these studies have generated contradictory claims. In one retrospective study [72], a database of 3,043 adults in the US hospitalized with laboratory-confirmed influenza during the 2007 to 2008 influenza season was analyzed. Of these patients, 1,013 received statins and 151 died within 30 days of their influenza test. The analysis revealed a positive correlation of statin use with reduced mortality. By contrast, when 1,520 patients in the UK [73] with confirmed 2009 pandemic influenza A (H1N1) infection were surveyed for preadmission statin use and in-hospital severity, no significant correlation could be found. Another recent study in Spain [74] examined the use of corticosteroids, macrolides and statins among 197 patients with 2009 pandemic influenza H1N1, who also had complications from pneumonia, suggesting a role of the inflammatory response. Unfortunately, none of these immunomodulatory therapies was found to be associated with a lower risk for developing severe disease. The apparent variability among some of these studies may be due to a number of factors [75], such as subtle differences in the viral genome sequence between the two pandemics, the dose and frequency of statin use, and environmental factors. Clearly, a more detailed, focused and controlled clinical trial is needed to evaluate the benefit of statin use, perhaps in conjunction with an antiviral agent such as oseltamivir or zanamivir.

\section{Sphingosine mimics}

Sphingolipids are a family of lipid mediators, of which sphingosine and its phosphate (sphingosine 1-phosphate or S1P) have been recognized as modulators of diverse cellular activities. The sphingosine analog family is a group of recent immunosuppressants with high therapeutic potential for influenza. In the body, these compounds mimic natural sphingosine and are first phosphorylated by sphingosine kinase $[76,77]$. The phosphoform then acts as an agonist of multiple types of sphingosine receptors, which leads to lymphopenia through the sequestration of lymphocytes in the lymph nodes, resulting in immunosuppression [76,77]. Fingolimod (FTY720) (Figure 2), an early member of this family (trade name Gilenya, from Novartis), is derived from a fungal metabolite and currently approved for treatment of autoimmune conditions, multiple sclerosis, cardiac failure and arrhythmia. Later, removal of a hydroxyl group in FTY720 generated AAL-4, which was much more rapidly phosphorylated in humans, improving its efficiency [78]. A series of studies have now 
shown that AAL-4 provides significant protection against the cytokine storm in pathogenic influenza by limiting pulmonary injury $[79,80]$. In a representative study [80], mice were intranasally infected with the pathogenic pandemic A/Wisconsin/WSLH34939/09 influenza virus and an hour later treated with AAL-R $(0.2 \mathrm{mg} / \mathrm{kg}$ in $100 \mu \mathrm{L}$ water intratracheally) or $100 \mu \mathrm{L}$ water alone. These animals with compared with those receiving $5 \mathrm{mg} / \mathrm{kg}$ (also in water) of oseltamivir (Tamiflu) by gavage. The results showed that AAL-R administration alone significantly lengthened the survival time of the animals $(82 \%)$ compared with those that received water. As expected, oseltamivir treatment alone significantly increased the number of survivors (50\%) compared with just water (21\%); however, protection was significantly less than that from AAL-R treatment (50\% versus $82 \%$ ). Interestingly, a combination of AAL-R and oseltamivir resulted in $96 \%$ survival, which is greater than either drug alone. Hence, a dual drug cocktail of a direct viral function inhibitor and a host immune response inhibitor may be a promising approach in the treatment of influenza.

\section{Nuclear factor-kappaB inhibitors}

$\mathrm{NF}-\kappa \mathrm{B}$ is a transcription factor of many genes of the cellular innate immune pathway and its activation underlies a variety of antiviral as well as inflammatory responses that range from septic shock to cancer. In fact, NF- $\kappa \mathrm{B}$ has been considered a major target of immunomodulatory and anti-inflammatory therapy $[81,82]$. In its interesting dual role, NF- $\kappa \mathrm{B}$ is not only a critical contributor of cytokines and interferon synthesis in influenza infection, but also essential for the growth of the virus itself [83-87]. Although the exact mechanism for the latter remains unclear, the balance must be tightly regulated, as the influenza viral NS1 protein actually inhibits NF- $\kappa \mathrm{B}$ [88]. Clearly, even after the inhibition, enough active NF$\kappa \mathrm{B}$ persists to promote viral growth and the inflammatory response. Thus, inhibitors of NF- $\kappa \mathrm{B}$ may have a two-pronged beneficial effect in influenza: they will inhibit the virus directly and will also moderate the systemic inflammation. This has been shown in cell culture and mice [84-86], but specific and controlled studies in patients with influenza still need to be done. Nonetheless, the prospects of an anti-inflammatory therapy of influenza are real, because some anti-NF- $\kappa \mathrm{B}$ drugs, such as acetyl salicylate (aspirin) are routinely sold in stores without prescription and widely used by the general public for many years without major side effects.

\section{Antimicrobial peptides and proteins}

A variety of animal and plant species produce small antimicrobial peptides and larger proteins that exhibit innate immune functions against an increasing number of pathogens. The two major families of antimicrobial peptides are defensins and cathelicidins (Figure 3) [89], whereas the collectins are larger proteins. Although antimicrobial peptides are diverse, they are generally cationic and amphipathic, which allows them to interact with and disrupt microbial membranes. In addition, they modulate the immune system by inducing the production of proinflammatory cytokines, act as chemokines for neutrophils and enhance phagocytosis of macrophages [89]. Recent studies have revealed antiviral including anti-influenza - activities of some of these molecules, some of which are presented here.

\section{Defensins}

The defensins typically contain six Cys residues, forming three intramolecular disulfide bonds that regulate their structure and function (Figure 3) [89]. They are

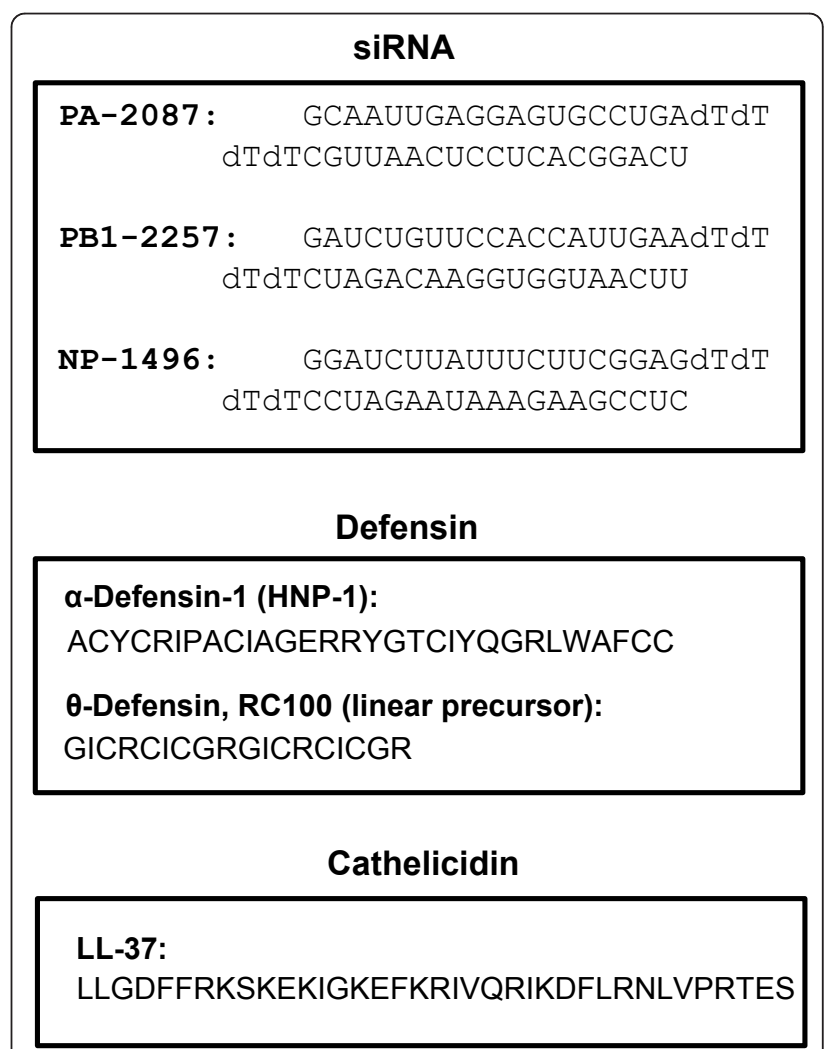

Figure 3 Sequences of selected anti-influenza macromolecules Three representative classes are shown (siRNA, defensin and cathelicidin). Experimentally successful siRNA against influenza PA, PB1 and NP genes are shown in the upper box [90]. For each siRNA, the location of the sequence in the original gene is indicated by nucleotide number; thus, PA-2087 indicates an siRNA in which the first nucleotide at position 2087 of the PA gene. The upper strand is written 5'to 3'; the two deoxythymidine (dT) at the 3'-end are presumed to stabilize the siRNA [91]. The lower box shows the 37mer peptide LL-37, written in single letter codes [92-94]. In the defensin family, note the abundance of Arg and Cys residues that are important for function [89]. 
subdivided into $\alpha$-, $\beta$ - and $\theta$-defensins, depending on their molecular weight and location of the Cys-Cys bonds. A number of defensins inhibited influenza virus growth, but the mechanism remains a matter of debate.

Humans have six $\alpha$-defensins, of which $\alpha$-defensin- 1 (also known as human neutrophil peptide-1, HNP-1) and $\alpha$-defensin-2 (HNP-2) were shown to increase neutrophil uptake of influenza virus $[95,96]$. The $\beta$-defensins had a significantly lower activity in this particular mechanism. In another study, HNP-1 (Figure 3) exhibited anti-influenza activity in epithelial cell culture as well, inhibiting viral RNA and protein synthesis [97]. Pretreatment of the cells with HNP-1 also inhibited viral replication, showing that the inhibition was due to modulation of cellular pathways. Protein kinase $\mathrm{C}$ was shown to be inhibited by HNP-1 treatment, suggesting the involvement of the protein kinase $C$ pathway in nonimmune cells.

The $\theta$-defensins, also called retrocyclins, are uniquely circular 18-residue peptides formed by post-translational joining of the $\mathrm{N}$ - and $\mathrm{C}$-termini of two nonapeptides, and they also occur exclusively in primates $[89,96]$. The human $\theta$-defensin genes are intriguing exceptions as they are pseudogenes harboring mutations that prevent the production of $\theta$-defensin proteins. Studies of nonhuman primate $\theta$-defensins have revealed that they are lectins with glycoprotein-binding properties that can inhibit fusion of HIV with the host cell, thus suggesting a novel antiviral regimen [98-101]. Human $\beta$-defensin 3 , another lectin, also inhibited HA-mediated influenza viral fusion in a similar way [101]. Recently, retrocyclin-1 (Figure 3) and its various synthetic analogs, some with structural variations (for example, hapivirins, diprovirins) were tested against influenza virus in human cell culture and shown to block infection at low micromolar concentrations $[99,101,102]$. The success of synthetic peptides has opened the possibility that further engineering of the defensin sequences may lead to more optimized anti-influenza efficacy and pharmacological properties $[100,103]$. In an interesting complementary approach, aminoglycosides (amikacin $40 \mu \mathrm{g} / \mathrm{mL}$; gentamicin $5 \mu \mathrm{g} / \mathrm{mL}$; tobramycin 10 $\mu \mathrm{g} / \mathrm{mL}$ ), which are known to promote suppression of termination by codon-misreading [104], were used to produce retrocyclin from the endogenous human genes, and this also resulted in resistance to HIV-1 [103]. Although aminoglycosides are sometimes prescribed to fight serious bacterial infections, nephrotoxicity and ototoxicity are relatively frequent [105]. It remains to be seen whether an optimized dose will generate enough retrocyclin to block influenza viral fusion without causing unacceptable toxic effects in the patient with influenza.

A few defensin mimetics are currently being developed by PolyMedix (Radnor, PA, USA) and are at various stages of preclinical and clinical trials, but apparently none is being tested against influenza.

\section{Cathelicidins: LL-37}

In humans, the cationic antimicrobial protein hCAP18 is cleaved between Ala103 and Leu104 to generate LL-37, a 37-residue peptide with two tandem Leu residues at the amino terminus (Figure 3). Recent studies are revealing these peptides are not just antibacterial molecules but have a variety of innate immune functions [92,93]. LL-37, which is expressed in a number of cell types including epithelial, was recently shown to protect mice against influenza [94]. Using a lethal dose of the two different influenza A strains (A/PR/8/34 H1N1 and A/Udorn/307/ 72 H3N2), significantly higher survival and decreased weight loss was observed in LL-37-treated animals, which compared favorably with the Relenza-treated positive controls. Although a part of the better prognosis could be due to suppression of the inflammatory response by LL-37, the accompanying lower pulmonary viral titer, the short window of the acute infection, and the reproducibility of the viral inhibition in cell culture all point to a direct antiviral role of LL-37, the mechanism of which remains to be determined [94]. The LL-37 in these mouse experiments was administered with a respiratory nebulizer at a concentration of $500 \mu \mathrm{g}$ per milliliter of saline and compared with the same concentration of Relenza [94]. At least in cell culture, the virus-inhibitory concentration of LL-37 approximated its natural concentration in the human lung [94]. LL-37, promising as it is, awaits further development for influenza treatment. It also remains to be seen whether other such antimicrobial peptides have antiviral, and specifically anti-influenza, properties. If so, this family may constitute an exciting and novel regimen for influenza treatment in the future.

\section{Collectins}

The collectins belong to the superfamily of collagencontaining C-type lectins (hence their name), and act as pattern recognition receptors for pathogenic molecules $[106,107]$. Better known members include the mannanbinding lectin and the surfactant proteins $\mathrm{A}$ and D. There is a large body of literature documenting an innate antiviral role of these lectins, in which they neutralize viral infectivity by binding to viral fusion glycoproteins, such as influenza viral HA and NA proteins; however, their contributions in opsonizing viral antigens and triggering neutrophil oxidative respiratory burst and an inflammatory response suggest that their pharmacological potential must await a more detailed analysis of these diverse roles [96,108-112].

\section{Short interfering RNA}

In all metazoan cells, double-stranded RNA (dsRNA) triggers a cascade of biochemical reactions, collectively named RNA interference (RNAi). The net result of RNAi is to silence or degrade any RNA that is complementary to either strand of the dsRNA. If the target is 
mRNA, the net result is abrogation of the corresponding protein synthesis, resulting in 'knockdown' of the gene (as opposed to 'knockout', in which the DNA gene itself is deleted). Of relevance to research scientists and clinicians, the RNAi response can be triggered by synthetic dsRNA 18 to 22 base-pairs long, called siRNA in both cell culture $[91,113]$ and in animals [114]. Historically, the first study demonstrating the antiviral use of appropriately designed synthetic siRNA targeted another respiratory virus, namely respiratory syncytial virus, a lower respiratory tract pathogen of paramount importance in pediatrics [113]. Antiinfluenza siRNAs followed soon after [90]. For both viruses, intranasally administered siRNA was promptly delivered to the lungs and showed significant efficacy and protection of animals [115-118]. For respiratory syncytial virus, an inhaler-based application was also found to be useful in the mouse model, which should work for influenza as well [114,117].

The siRNAs in general enjoy several advantages over organic chemical drugs (such as Tamiflu and Relenza) [117]. First, the siRNA 'drugs' can be rapidly synthesized and scaled up for production. Second, in the event of viral resistance to one siRNA, a different siRNA targeting another viral sequence can be used. Third, regardless of sequence, all siRNAs use the same synthetic chemistry and hence the same manufacturing process. Finally, unlike many pharmacologically active organic compounds, siRNAs are water-soluble. Nonetheless, a clinically viable anti-influenza siRNA must meet a number of criteria, including specific tissue delivery (lung and the adjoining airspace), low toxicity and immune reaction, and pharmacokinetic stability.

A number of siRNA sequences, targeting various genes of influenza virus (Figure 3), have been tested over the last few years [90,115,118-120]. Recently, with better knowledge of siRNA design parameters and availability of appropriate bioinformatic algorithms, a more comprehensive siRNA repertoire covering a larger number of influenza viral genes in a variety of strains and isolates has been published [121-123]. Although no siRNA is yet commercially available for influenza treatment, Siranomics, Inc. (Gaithersburg, MD, USA) is developing the proprietary STP702 (FluQuit), a cocktail of siRNA designed to inhibit conserved regions in H1N1 and H5N1 strains of the influenza virus [124]. The ultimate goal would be to develop STP702 with demonstrated activity against multiple influenza A strains including H1N1, H5N1, H3N2, H7N2 and H9N2 [124].

\section{Drugs targeting the 'host interactome' of influenza}

The limited number of influenza genes that can be targeted and the problems of resistance have made the targeting of host genes that are necessary for virus growth, nicknamed host interactome [125], an attractive new paradigm. It is also built on the premise that short-term inhibition of these host functions to treat an acute infection would not have major side effects. The concept of pharmacologically relevant genes, commonly called druggable genes, already exists. For example, essentially all successful cancer chemotherapeutic drugs target host functions. The anti-HIV drug, maraviroc, targets the viral co-receptor $\mathrm{C}-\mathrm{C}$ chemokine receptor 5 , and thereby prevents vial entry [126].

In the past few years, a number of comprehensive, genome-wide studies have identified host genes essential for virus growth, primarily through the use of siRNA libraries against the host genome and innovative, highthroughput reporter viral assays. In influenza, at least five such studies were conducted that used diverse readouts in different cell types, multiple virus strains and siRNA libraries targeting about 22,000 host genes [127-131]. Each screen identified a few hundred hits; intriguingly, however, not one hit was common to all five screens, perhaps underscoring the differences in their methodology and assay variables. Nonetheless, analysis of the hits revealed genes common to subsets of screens; for example, 85 genes were common to two or more of the screens, 72 genes were common to two of the five screens, 8 were common to three screens, and 5 were common to four screens [125]. These five genes code for: archain 1, ATPase, $\mathrm{H}^{+}$transporting, lysosomal accessory protein 1 , coatamer protein complex, $\alpha$ subunit, coatamer protein complex, $\gamma$ subunit, and nuclear RNA export factor 1 . The functional categories, over-represented in the 85 cellular genes mentioned above, include ribosomal proteins, COPI (coat protein) vesicles, ATPase complex, spliceosomal proteins, nuclear envelope and kinase/signaling proteins, which underscores the many areas of the host that the virus co-opts $[125,132]$. Of these, nearly 50 are considered druggable, according to the Integrated Druggable Genome Database available from Sophic (http://www.sophicalliance.com/) [125,133], many of which can be pursued as targets of anti-influenza drug discovery. A few leads have been already confirmed by gene-specific analysis $[125,134,135]$. For example, an inhibitor (KN93; Figure 2) of the $\mathrm{Ca}^{+2} /$ calmodulindependent kinase (CAMK2B), a gene identified in one genome-wide screen [131], inhibited influenza virus replication. Similarly, an inhibitor (TG003) of the CDlike kinase 1 that was found from another screen [130] also inhibited influenza virus growth. The third example is of p27, also found in the same screen [130]; the p27 knockout mice were found to be not only viable but also substantially resistant to virus growth, suggesting that p27 is a viable drug target.

In a separate recent screen, host genes specifically important for influenza viral polymerase (RdRP) function were identified, which are also potential candidates for antiviral drug development [136]. A chemical biology 
screen of 200,000 synthetic compounds recently identified naphthalimides as an antiviral chemical class that activated a new host defense factor, REDD1, which in turn inhibited influenza NS1 and viral replication [137]. Thus, activation of REDD1, rather than inhibition, can be developed as a new anti-influenza regimen.

\section{Conclusion}

The current influenza treatments (Tamiflu, Relenza) target the viral NA and are quite effective. However, history has taught us that the virus mutates rapidly and becomes resistant to antivirals, as exemplified by the discontinuation of the once-effective adamantanes, the viral M2 inhibitor family. Viral resistance against the NA inhibitors has in fact begun to emerge recently, and their continuous use may lead to wide-spread selection of such mutants, making the population vulnerable to a drugresistant epidemic. It is clearly important to have new antivirals in our anti-influenza arsenal. Based on research efforts, there appears to be five promising new anti-influenza regimens. The first of these is new compounds screened against old and new viral targets, such as NA, $\mathrm{HA}$, the $\mathrm{N}$ protein [138] and RdRP subunits, or even the M2 ion channel [139]. Recall that NS1 is a major antiimmune function of the virus, and drug development against it has recently begun [140], with the identification of one inhibitory compound, NSC125044 (Figure 2) that reduced virus growth to virtually the same extent as an NS1-deleted virus. Clearly, these studies are promising, and need to be expanded. The second possible regime comprises siRNA, provided that the recognized hurdles of siRNA delivery, stability and specificity are resolved to a clinically acceptable level $[141,142]$. Third are new treatments that target any of the recently identified druggable host factors, essential for virus replication. Fourth, multiple drugs cocktail, targeting two viral functions [143] or one viral and one cellular function can be developed, the latter including inflammatory players (for example, NF- $\kappa \mathrm{B}$, sphingosine, chemokines) commonly activated in influenza. Finally the fifth possibility for new anti-influenza regimens is naturally occurring innate immune peptides, such as defensins and cathelicidins, that can be further optimized for a proper balance between their anti-influenza and signaling effects.

\section{Author information}

The author is a Professor at the Department of Biological, Geological and Environmental Sciences and is also Director of the Center for Gene Regulation in Health and Disease at the Cleveland State University. He holds adjunct appointment in the Department of Molecular Genetics at the Cleveland Clinic, Cleveland, Ohio.

\section{Abbreviations}

dsRNA: double-stranded RNA; HA: hemagglutinin; HNP: human neutrophil peptide; M2: matrix protein 2; NA: neuraminidase; NF-KB: nuclear factor kappa B; NP: nucleocapsid protein; NS: nonstructural; RdRP: RNA-dependent RNA polymerase; RNAi: RNA interference; siRNA: short (or small) interfering RNA.

\section{Acknowledgements}

Research in the author's laboratory was supported by National Institute of Health grant Al059267. The author sincerely thanks the Centers for Disease Control and Prevention and the National Center for Biotechnology Information, USA, for free access to their databases that were used in this article.

\section{Author details}

${ }^{1}$ Center for Gene Regulation in Health and Disease, Cleveland State University, 2351 Euclid Avenue, Cleveland, Ohio 44115, USA. ${ }^{2}$ Department of Biological, Geological and Environmental Sciences, Cleveland State University, 2121 Euclid Avenue, Cleveland, Ohio 44115, USA.

\section{Competing interests}

The author is a Scientific Founder of Sirnaomics, Inc.

Received: 24 April 2012 Accepted: 13 September 2012

Published: 13 September 2012

\section{References}

1. WHO: Influenza (seasonal). 2009 [http://www.who.int/mediacentre/ factsheets/fs211/en/]

2. Metersky ML, Masterton RG, Lode H, File TM Jr, Babinchak T: Epidemiology, microbiology, and treatment considerations for bacterial pneumonia complicating influenza. Int J Infect Dis 2012, 16:e321-331.

3. Hale BG, Albrecht RA, García-Sastre A: Innate immune evasion strategies of influenza viruses. Future Microbiol 2010, 5:23-41.

4. Palese P, Shaw ML: Orthomyxoviridae: the viruses and their replication. In Fields Virology.. 5 edition. Edited by: Knipe DM, Howley PM. Philadelphia, PA: Lippincott Williams 2007:1647-1689.

5. Morens DM, Taubenberger JK, Fauci AS: Predominant role of bacterial pneumonia as a cause of death in pandemic influenza: implications for pandemic influenza preparedness. J Infect Dis 2008, 198:962-970.

6. Haessler S, Paez A, Rothberg M, Higgins T: 2009 pandemic H1N1associated myocarditis in a previously healthy adult. Clin Microbiol Infect 2011, 17:572-574.

7. Kumar K, Guirgis M, Zieroth S, Lo E, Menkis AH, Arora RC, Freed DH: Influenza myocarditis and myositis: case presentation and review of the literature. Can J Cardiol 2011, 27:514-522.

8. Pan HY, Yamada H, Chida J, Wang S, Yano M, Yao M, Zhu J, Kido H: Upregulation of ectopic trypsins in the myocardium by influenza $A$ virus infection triggers acute myocarditis. Cardiovasc Res 2011, 89:595-603.

9. Ru YX, Li YC, Zhao Y, Zhao SX, Yang JP, Zhang HM, Pang TX: Multiple organ invasion by viruses: pathological characteristics in three fatal cases of the 2009 pandemic influenza A/H1N1. Ultrastruct Pathol 2011, 35:155-161.

10. Toffan A, Serena Beato M, De Nardi R, Bertoli E, Salviato A, Cattoli G, Terregino C, Capua I: Conventional inactivated bivalent $\mathrm{H} 5 / \mathrm{H} 7$ vaccine prevents viral localization in muscles of turkeys infected experimentally with low pathogenic avian influenza and highly pathogenic avian influenza H7N1 isolates. Avian Pathol 2008, 37:407-412.

11. Bitko V, Musiyenko A, Barik S: Viral infection of the lungs through the eye. J Virol 2007, 81:783-790.

12. Chen W, Calvo PA, Malide D, Gibbs J, Schubert U, Bacik I, Basta S, O'Neill R, Schickli J, Palese P, Henklein P, Bennink JR, Yewdell JW: A novel influenza $A$ virus mitochondrial protein that induces cell death. Nat Med 2001, 7:1306-1312.

13. Krug RM, Aramini JM: Emerging antiviral targets for influenza A virus. Trends Pharmacol Sci 2009, 30:269-277.

14. Marazzi I, Ho JS, Kim J, Manicassamy B, Dewell S, Albrecht RA, Seibert CW, Schaefer U, Jeffrey KL, Prinjha RK, Lee K, García-Sastre A, Roeder RG, Tarakhovsky A: Suppression of the antiviral response by an influenza histone mimic. Nature 2012, 483:428-433. 
15. Munir M, Zohari S, Belák S, Berg M: Double-stranded RNA-induced activation of activating protein-1 promoter is differentially regulated by the non-structural protein 1 of avian influenza A viruses. Viral Immunol 2012, 25:79-85.

16. Lin L, Li Y, Pyo HM, Lu X, Raman SN, Liu Q, Brown EG, Zhou Y: Identification of RNA helicase $A$ as a cellular factor that interacts with influenza A virus NS1 protein and its role in the virus life cycle. J Virol 2012, 86:1942-1954.

17. Golebiewski L, Liu H, Javier RT, Rice AP: The avian influenza virus NS1 ESEV PDZ binding motif associates with Dlg1 and Scribble to disrupt cellular tight junctions. J Virol 2011, 85:10639-10648.

18. Billharz R, Zeng H, Proll SC, Korth MJ, Lederer S, Albrecht R, Goodman AG, Rosenzweig E, Tumpey TM, García-Sastre A, Katz M: The NS1 protein of the 1918 pandemic influenza virus blocks host interferon and lipid metabolism pathways. J Virol 2009, 83:10557-10570.

19. Kochs G, García-Sastre A, Martínez-Sobrido L: Multiple anti-interferon actions of the influenza A virus NS1 protein. J Virol 2007, 81:7011-7021.

20. Gack MU, Albrecht RA, Urano T, Inn KS, Huang IC, Carnero E, Farzan M, Inoue S, Jung JU, García-Sastre A: Influenza A virus NS1 targets the ubiquitin ligase TRIM25 to evade recognition by the host viral RNA sensor RIG-I. Cell Host Microbe 2009, 5:439-449.

21. Forbes NE, Ping J, Dankar SK, Jia JJ, Selman M, Keleta L, Zhou Y, Brown EG: Multifunctional adaptive NS1 mutations are selected upon human influenza virus evolution in the mouse. PLoS One 2012, 7:e31839.

22. Ayllon J, Hale BG, García-Sastre A: Strain-specific contribution of NS1 activated phosphoinositide 3-kinase signaling to influenza $A$ virus replication and virulence. J Virol 2012, 86:5366-5370.

23. Noronha JM, Liu M, Squires RB, Pickett BE, Hale BG, Air GM, Galloway SE, Takimoto T, Schmolke M, Hunt V, Klem E, García-Sastre A, McGee M, Scheuermann RH: Influenza Sequence Feature Variant Type (Flu-SFVT) analysis: evidence for a role of NS1 in influenza host range restriction. J Virol 2012, 86:5857-5866.

24. Versteeg GA, Hale BG, van Boheemen S, Wolff T, Lenschow DJ, GarcíaSastre A: Species-specific antagonism of host ISGylation by the influenza B virus NS1 protein. J Virol 2010, 84:5423-5430.

25. Webster RG, Bean WJ, Gorman OT, Chambers TM, Kawaoka Y: Evolution and ecology of influenza A viruses. Microbiol Rev 1992, 56:152-179.

26. Koopmans $M$, Wilbrink $B$, Conyn $M$, Natrop $G$, van der Nat $H$, Vennema $H$, Meijer A, van Steenbergen J, Fouchier R, Osterhaus A, Bosman A: Transmission of H7N7 avian influenza A virus to human beings during a large outbreak in commercial poultry farms in the Netherlands. Lancet 2004, 363:587-593.

27. Claas EC, Osterhaus AD, van Beek R, De Jong JC, Rimmelzwaan GF, Senne DA, Krauss S, Shortridge KF, Webster RG: Human influenza A H5N1 virus related to a highly pathogenic avian influenza virus. Lancet 1998, 351:472-477.

28. Kuiken T, Holmes EC, McCauley J, Rimmelzwaan GF, Williams CS, Grenfell BT: Host species barriers to influenza virus infections. Science 2006, 312:394-397.

29. Centers for Disease Control and Prevention: Seasonal influenza (flu) information on H3N2 variant influenza A viruses.[http://www.cdc.gov/flu/ swineflu/influenza-variant-viruses-h3n2v.htm]

30. Darwish I, Mubareka S, Liles WC: Immunomodulatory therapy for severe influenza. Expert Rev Anti Infect Ther 2011, 9:807-822.

31. Tisoncik JR, Korth MJ, Simmons CP, Farrar J, Martin TR, Katze MG: Into the eye of the cytokine storm. Microbiol Mol Biol Rev 2012, 76:16-32.

32. Yuen KY, Chan PK, Peiris M, Tsang DN, Que TL, Shortridge KF, Cheung PT, To WK, Ho ET, Sung R, Cheng AF: Clinical features and rapid viral diagnosis of human disease associated with avian influenza A H5N1 virus. Lancet 1998, 351:467-471.

33. Wong SS, Yuen KY: Avian influenza virus infections in humans. Chest 2006, 129:156-168.

34. Writing Committee of the Second World Health Organization Consultation on Clinical Aspects of Human Infection with Aavian Influenza A (H5N1) Virus, Abdel-Ghafar AN, Chotpitayasunondh T, Gao Z, Hayden FG, Nguyen DH, de J, Naghdaliyev A, Peiris JS, Shindo N, Soeroso S, Uyeki TM: Update on avian influenza A (H5N1) virus infection in humans. N Engl J Med 2008, 358:261-273.

35. Cheung CY, Poon LL, Lau AS, Luk W, Lau YL, Shortridge KF, Gordon S, Guan $Y$, Peiris JS: Induction of proinflammatory cytokines in human macrophages by influenza A (H5N1) viruses: a mechanism for the unusual severity of human disease? Lancet 2002, 360:1831-1837.

36. Ison MG, Gnann JW Jr, Nagy-Agren S, Treannor J, Paya C, Steigbigel R, Elliott M, Weiss HL, Hayden FG: Safety and efficacy of nebulized zanamivir in hospitalized patients with serious influenza. Antivir Ther 2003, 8:183-190.

37. Wolf Yl, Viboud C, Holmes EC, Koonin EV, Lipman DJ: Long intervals of stasis punctuated by bursts of positive selection in the seasonal evolution of influenza A virus. Biol Direct 2006, 1:34

38. Webby RJ, Webster RG: Emergence of influenza A viruses. Philos Trans $R$ Soc Lond B Biol Sci 2001, 356:1817-1828.

39. Patterson KD, Pyle GF: The geography and mortality of the 1918 influenza pandemic. Bull Hist Med 1991, 65:4-21.

40. Taubenberger JK, Reid AH, Janczewski TA, Fanning TG: Integrating historical, clinical and molecular genetic data in order to explain the origin and virulence of the 1918 Spanish influenza virus. Philos Trans $R$ Soc Lond B Biol Sci 2001, 356:1829-1839.

41. Dunham EJ, Dugan VG, Kaser EK, Perkins SE, Brown IH, Holmes EC, Taubenberger JK: Different evolutionary trajectories of European avianlike and classical swine H1N1 influenza A viruses. J Virol 2009, 83:5485-5494.

42. Garten RJ, Davis CT, Russell CA, Shu B, Lindstrom S, Balish A, Sessions WM, Xu X, Skepner E, Deyde V, Okomo-Adhiambo M, Gubareva L, Barnes J, Smith CB, Emery SL, Hillman MJ, Rivailler P, Smagala J, de Graaf M, Burke DF, Fouchier RA, Pappas C, Alpuche-Aranda CM, López-Gatell H, Olivera H, López I, Myers CA, Faix D, Blair PJ, Yu C, et al: Antigenic and genetic characteristics of swine-origin 2009 A (H1N1) influenza viruses circulating in humans. Science 2009, 325:197-201.

43. Sheu TG, Fry AM, Garten RJ, Deyde VM, Shwe T, Bullion L, Peebles PJ, Li Y, Klimov Al, Gubareva LV: Dual resistance to adamantanes and oseltamivir among seasonal influenza A(H1N1) viruses: 2008-2010. J Infect Dis 2011 203:13-17.

44. Bolton E, Wang Y, Thiessen PA, Bryant SH: PubChem: Integrated platform of small molecules and biological activities. In Annual Reports in Computational Chemistry. Volume 4. Edited by: Wheeler RA, Spellmeyer DC Washington, DC: American Chemical Society/Elsevier; 2008:217-241.

45. Luo M: Influenza virus entry. Adv Exp Med Biol 2012, 726:201-221.

46. Das K, Aramini JM, Ma LC, Krug RM, Arnold E: Structures of influenza A proteins and insights into antiviral drug targets. Nat Struct Mol Biol 2010, 17:530-538

47. von Itzstein M, Wu WY, Kok GB, Pegg MS, Dyason JC, Jin B, Van Phan T, Smythe ML, White HF, Oliver SW: Rational design of potent sialidasebased inhibitors of influenza virus replication. Nature 1993, 363:418-423.

48. McKimm-Breschkin JL, Selleck PW, Usman TB, Johnson MA: Reduced sensitivity of influenza A (H5N1) to oseltamivir. Emerg Infect Dis 2007, 13:1354-1357.

49. Hurt AC, Holien JK, Parker MW, Barr IG: Oseltamivir resistance and the $\mathrm{H} 274 \mathrm{Y}$ neuraminidase mutation in seasonal, pandemic and highly pathogenic influenza viruses. Drugs 2009, 69:2523-2531.

50. Sugaya N, Ohashi Y: Long-acting neuraminidase inhibitor laninamivir octanoate (CS-8958) versus oseltamivir as treatment for children with influenza virus infection. Antimicrob Agents Chemother 2010, 54:2575-2582.

51. Ikematsu $H$, Kawai $\mathrm{N}$ : Laninamivir octanoate: a new long-acting neuraminidase inhibitor for the treatment of influenza. Expert Rev Anti Infect Ther 2011, 9:851-857.

52. Chairat K, Tarning J, White NJ, Lindegardh N: Pharmacokinetic properties of anti-influenza neuraminidase inhibitors. J Clin Pharmacol 2012.

53. Richard $M$, Ferraris $O$, Erny A, Barthélémy $M$, Traversier A, Sabatier M, Hay A, Lin YP, Russell RJ, Lina B: Combinatorial effect of two framework mutations (E119V and I222L) in the neuraminidase active site of H3N2 influenza virus on resistance to oseltamivir. Antimicrob Agents Chemother 2011, 55:2942-2952.

54. Meijer A, Lackenby A, Hungnes $O$, Lina B, van-der-Werf S, Schweiger B, Opp M, Paget J, van-de-Kassteele J, Hay A, Zambon M: Oseltamivirresistant influenza virus $\mathrm{A}(\mathrm{H} 1 \mathrm{~N} 1)$, Europe, 2007-08 season. Emerg Infect Dis 2009, 15:552-560.

55. Duan S, Boltz DA, Seiler P, Li J, Bragstad K, Nielsen LP, Webby RJ, Webster RG, Govorkova EA: Oseltamivir-resistant pandemic H1N1/2009 influenza virus possesses lower transmissibility and fitness in ferrets. PLoS Pathog 2010, 6:e1001022. 
56. Baranovich T, Webster RG, Govorkova EA: Fitness of neuraminidase inhibitor-resistant influenza A viruses. Curr Opin Virol 2011, 1:574-581.

57. Fiore AE, Fry A, Shay D, Gubareva L, Bresee JS, Uyeki TM, Centers for Disease Control and Prevention (CDC): Antiviral agents for the treatment and chemoprophylaxis of influenza - recommendations of the Advisory Committee on Immunization Practices (ACIP). MMWR Recomm Rep 2011 60:1-24

58. Vavricka CJ, Li Q, Wu Y, Qi J, Wang M, Liu Y, Gao F, Liu J, Feng E, He J, Wang J, Liu H, Jiang H, Gao GF: Structural and functional analysis of laninamivir and its octanoate prodrug reveals group specific mechanisms for influenza NA inhibition. PLoS Pathog 2011, 7:e1002249.

59. Furuta Y, Takahashi K, Fukuda Y, Kuno M, Kamiyama T, Kozaki K, Nomura N, Egawa $H$, Minami S, Watanabe $Y$, Narita $H$, Shiraki $K$ : In vitro and in vivo activities of anti-influenza virus compound T-705. Antimicrob Agents Chemother 2002, 46:977-981.

60. Kiso M, Takahashi K, Sakai-Tagawa Y, Shinya K, Sakabe S, Le QM, Ozawa M, Furuta Y, Kawaoka Y: T-705 (favipiravir) activity against lethal H5N1 influenza A viruses. Proc Natl Acad Sci USA 2010, 107:882-887.

61. Jones JC, Turpin EA, Bultmann H, Brandt CR, Schultz-Cherry S: Inhibition of influenza virus infection by a novel antiviral peptide that targets viral attachment to cells. J Virol 2006, 80:11960-11967.

62. Rajik M, Jahanshiri F, Omar AR, Ideris A, Hassan SS, Yusoff K: Identification and characterisation of a novel anti-viral peptide against avian influenza virus H9N2. Virol J 2009, 6:74.

63. Belser JA, Lu X, Szretter KJ, Jin X, Aschenbrenner LM, Lee A, Hawley S, Kim do H, Malakhov MP, Yu M, Fang F, Katz JM: DAS181, a novel sialidase fusion protein, protects mice from lethal avian influenza $\mathrm{H} 5 \mathrm{~N} 1$ virus infection. J Infect Dis 2007, 196:1493-1499.

64. Triana-Baltzer GB, Gubareva LV, Nicholls JM, Pearce MB, Mishin VP, Belser JA, Chen LM, Chan RW, Chan MC, Hedlund M, Larson JL, Moss RB, Katz JM, Tumpey TM, Fang F: Novel pandemic influenza $A(\mathrm{H} 1 \mathrm{~N} 1)$ viruses are potently inhibited by DAS181, a sialidase fusion protein. PLOS One 2009, 4:e7788.

65. Liao JK: Beyond lipid lowering: the role of statins in vascular protection. Int J Cardiol 2002, 86:5-18.

66. Marz W, Koenig W: HMG-CoA reductase inhibition: anti-inflammatory effects beyond lipid lowering? J Cardiovasc Risk 2003, 10:169-179.

67. Ludwig S: Targeting cell signalling pathways to fight the flu: towards a paradigm change in anti-influenza therapy. J Antimicrob Chemother 2009, 64:1-4.

68. Viemann D, Schmolke M, Lueken A, Boergeling Y, Friesenhagen J, Wittkowski H, Ludwig S, Roth J: H5N1 virus activates signaling pathways in human endothelial cells resulting in a specific imbalanced inflammatory response. J Immunol 2011, 186:164-173.

69. Prospective Studies Collaboration, Lewington S, Whitlock G, Clarke R, Sherliker P, Emberson J, Halsey J, Qizilbash N, Peto R, Collins R: Blood cholesterol and vascular mortality by age, sex, and blood pressure: a meta-analysis of individual data from 61 prospective studies with 55,000 vascular deaths. Lancet 2007, 370:1829-1839.

70. Fedson DS: Pandemic influenza: a potential role for statins in treatment and prophylaxis. Clin Infect Dis 2006, 43:199-205

71. Enserink M: Infectious disease. Old drugs losing effectiveness against flu; could statins fill gap? Science 2005, 309:1976-1977.

72. Vandermeer ML, Thomas AR, Kamimoto L, Reingold A, Gershman K, Meek J, Farley MM, Ryan P, Lynfield R, Baumbach J, Schaffner W, Bennett N, Zansky S: Association between use of statins and mortality among patients hospitalized with laboratory-confirmed influenza virus infections: a multistate study. J Infect Dis 2012, 205:13-19.

73. Brett SJ, Myles P, Lim WS, Enstone JE, Bannister B, Semple MG, Read RC, Taylor BL, McMenamin J, Nicholson KG, Nguyen-Van-Tam JS, Openshaw PJ, Influenza Clinical Information Network (FLU-CIN): Pre-admission statin use and in-hospital severity of 2009 pandemic influenza $A(H 1 N 1)$ disease. PLoS One 2011, 6:e18120.

74. Viasus D, Paño-Pardo JR, Cordero E, Campins A, López-Medrano F, Villoslada A, Fariñas MC, Moreno A, Rodríguez-Baño J, Oteo JA, MartínezMontauti J, Torre-Cisneros J, Segura F, Carratalà J, Novel Influenza A (H1N1) Study Group, Spanish Network for Research in Infectious Diseases: Effect of immunomodulatory therapies in patients with pandemic influenza A (H1N1) 2009 complicated by pneumonia. J Infect 2011, 62:193-199.

75. De Loecker I, Preiser JC: Statins in the critically ill. Ann Intensive Care 2012, 2:19.
76. Billich A, Bornancin F, Dévay P, Mechtcheriakova D, Urtz N, and Baumruker T: Phosphorylation of the immunomodulatory drug FTY720 by sphingosine kinases. J Biol Chem 2003, 278:47408-47415.

77. Zemann B, Kinzel B, Müller M, Reuschel R, Mechtcheriakova D, Urtz N, Bornancin F, Baumruker T, Billich A: Sphingosine kinase type 2 is essential for lymphopenia induced by the immunomodulatory drug FTY720. Blood 2006, 107:1454-1458.

78. Jary E, Bee T, Walker SR, Chung SK, Seo KC, Morris JC, Don AS: Elimination of a hydroxyl group in FTY720 dramatically improves the phosphorylation rate. Mol Pharmacol 2010, 78:685-692.

79. Marsolais D, Hahm B, Walsh KB, Edelmann KH, McGavern D, Hatta Y, Kawaoka $Y$, Rosen $H$, Oldstone MB: A critical role for the sphingosine analog $A A L-R$ in dampening the cytokine response during influenza virus infection. Proc Natl Acad Sci USA 2009, 106:1560-1565.

80. Walsh KB, Teijaro JR, Wilker PR, Jatzek A, Fremgen DM, Das SC, Watanabe T, Hatta M, Shinya K, Suresh M: Suppression of cytokine storm with a sphingosine analog provides protection against pathogenic influenza virus. Proc Natl Acad Sci USA 2011, 108:12018-12023.

81. Hayden MS, Ghosh S: NF-kB, the first quarter-century: remarkable progress and outstanding questions. Genes Dev 2012, 26:203-234.

82. Rahman A, Fazal F: Blocking NF-kB: an inflammatory issue. Proc Am Thorac Soc 2011, 8:497-503.

83. Nimmerjahn F, Dudziak D, Dirmeier U, Hobom G, Riedel A, Schlee M, Staudt LM, Rosenwald A, Behrends U, Bornkamm GW, Mautner J: Active NF-kappaB signalling is a prerequisite for influenza virus infection. $J$ Gen Virol 2004, 85:2347-2356.

84. Mazur I, Wurzer WJ, Ehrhardt C, Pleschka S, Puthavathana P, Silberzahn T, Wolff T, Planz O, Ludwig S: Acetylsalicylic acid (ASA) blocks influenza virus propagation via its NF-kappaB-inhibiting activity. Cell Microbiol 2007, 9:1683-1694

85. Pinto R, Herold S, Cakarova L, Hoegner K, Lohmeyer J, Planz O, Pleschka S: Inhibition of influenza virus-induced NF-kappaB and Raf/MEK/ERK activation can reduce both virus titers and cytokine expression simultaneously in vitro and in vivo. Antiviral Res 2011, 92:45-56.

86. Wiesener N, Zimmer C, Jarasch-Althof N, Wutzler P, Henke A: Therapy of experimental influenza virus infection with pyrrolidine dithiocarbamate. Med Microbiol Immunol 2011, 200:115-126.

87. Schmolke M, Viemann D, Roth J, Ludwig S: Essential impact of NF-kappaB signaling on the $\mathrm{H} 5 \mathrm{~N} 1$ influenza A virus-induced transcriptome. $J$ Immunol 2009, 183:5180-5189.

88. Wang X, Li M, Zheng H, Muster T, Palese P, Beg AA, García-Sastre A: Influenza A virus NS1 protein prevents activation of NF-kappaB and induction of alpha/beta interferon. J Virol 2000, 74:11566-11573.

89. Cederlund A, Gudmundsson GH, Agerberth B: Antimicrobial peptides important in innate immunity. FEBS J 2011, 278:3942-3951.

90. Ge Q, McManus MT, Nguyen T, Shen CH, Sharp PA, Eisen HN, Chen J: RNA interference of influenza virus production by directly targeting mRNA for degradation and indirectly inhibiting all viral RNA transcription. Proc Natl Acad Sci USA 2003, 100:2718-2723.

91. Elbashir SM, Harborth J, Lendeckel W, Yalcin A, Weber K, Tuschl T: Duplexes of 21-nucleotide RNAs mediate RNA interference in cultured mammalian cells. Nature 2001, 411:494-498.

92. Bals R, Weiner DJ, Moscioni AD, Meegalla RL, Wilson JM: Augmentation of innate host defense by expression of a cathelicidin antimicrobial peptide. Infect Immun 1999, 67:6084-6089.

93. Bals R, Wang X, Zasloff M, Wilson JM: The peptide antibiotic LL-37/hCAP18 is expressed in epithelia of the human lung where it has broad antimicrobial activity at the airway surface. Proc Natl Acad Sci USA 1998, 95:9541-9546.

94. Barlow PG, Svoboda P, Mackellar A, Nash AA, York IA, Pohl J, Davidson DJ, Donis RO: Antiviral activity and increased host defense against influenza infection elicited by the human cathelicidin LL-37. PLoS One 2011, 6:e25333.

95. Tecle T, White MR, Gantz D, Crouch EC, Hartshorn KL: Human neutrophil defensins increase neutrophil uptake of influenza A virus and bacteria and modify virus-induced respiratory burst responses. J Immunol 2007, 178:8046-8052.

96. Doss M, White MR, Tecle T, Gantz D, Crouch EC, Jung G, Ruchala P, Waring AJ, Lehrer RI, Hartshorn KL: Interactions of alpha-, beta-, and theta-defensins with influenza A virus and surfactant protein D. $\mathrm{J}$ Immunol 2009, 182:7878-7887. 
97. Salvatore M, Garcia-Sastre A, Ruchala P, Lehrer RI, Chang T, Klotman ME: alpha-Defensin inhibits influenza virus replication by cell-mediated mechanism(s). J Infect Dis 2007, 196:835-843.

98. Cole AM, Hong T, Boo LM, Nguyen T, Zhao C, Bristol G, Zack JA, Waring AJ, Yang OO, Lehrer RI: Retrocyclin: a primate peptide that protects cells from infection by T- and M-tropic strains of HIV-1. Proc Natl Acad Sci USA 2002, 99:1813-1818.

99. Wang W, Cole AM, Hong T, Waring AJ, Lehrer Rl: Retrocyclin, an antiretroviral theta-defensin, is a lectin. J Immunol 2003, 170:4708-4716.

100. Owen SM, Rudolph DL, Wang W, Cole AM, Waring AJ, Lal RB, Lehrer RI: RC101, a retrocyclin-1 analogue with enhanced activity against primary HIV type 1 isolates. AIDS Res Hum Retroviruses 2004, 20:1157-1165.

101. Leikina E, Delanoe-Ayari H, Melikov K, Cho MS, Chen A, Waring AJ, Wang W, Xie Y, Loo JA, Lehrer Rl, Chernomordik LV: Carbohydrate-binding molecules inhibit viral fusion and entry by crosslinking membrane glycoproteins. Nat Immunol 2005, 6:995-1001.

102. Doss M, Ruchala P, Tecle T, Gantz D, Verma A, Hartshorn A, Crouch EC, Luong H, Micewicz ED, Lehrer Rl, Hartshorn KL: Hapivirins and diprovirins: novel $\theta$-defensin analogs with potent activity against influenza $A$ virus. $\mathrm{J}$ Immunol 2012, 188:2759-2768.

103. Venkataraman N, Cole AL, Ruchala P, Waring AJ, Lehrer RI, Stuchlik O, Pohl J, Cole AM: Reawakening retrocyclins: ancestral human defensins active against HIV-1. PLoS Biol 2009, 7:e95.

104. Lynch SR, Puglisi JD: Structure of a eukaryotic decoding region A-site RNA. J Mol Biol 2001, 306:1023-1035.

105. Durante-Mangoni E, Grammatikos A, Utili R, Falagas ME: Do we still need the aminoglycosides? Int J Antimicrob Agents 2009, 33:201-205.

106. Chroneos ZC, Sever-Chroneos Z, Shepherd VL: Pulmonary surfactant: an immunological perspective. Cell Physiol Biochem 2010, 25:13-26.

107. Seaton BA, Crouch EC, McCormack FX, Head JF, Hartshorn KL, Mendelsohn R: Structural determinants of pattern recognition by lung collectins. Innate Immun 2010, 16:143-150.

108. White MR, Crouch E, Vesona J, Tacken PJ, Batenburg JJ, Leth-Larsen R, Holmskov U, Hartshorn KL: Respiratory innate immune proteins differentially modulate the neutrophil respiratory burst response to influenza A virus. Am J Physiol Lung Cell Mol Physiol 2005, 289:L606-616

109. Reading PC, Tate MD, Pickett DL, Brooks AG: Glycosylation as a target for recognition of influenza viruses by the innate immune system. Adv Exp Med Biol 2007, 598:279-292.

110. Tecle T, White MR, Crouch EC, Hartshorn KL: Inhibition of influenza viral neuraminidase activity by collectins. Arch Virol 2007, 152:1731-1742.

111. Hartshorn KL, White MR, Tecle T, Sorensen G, Holmskov U, Crouch EC: Viral aggregating and opsonizing activity in collectin trimers. Am J Physiol Lung Cell Mol Physiol 2010, 298:L79-88.

112. Ling MT, Tu W, Han Y, Mao H, Chong WP, Guan J, Liu M, Lam KT, Law HK, Peiris JS, Takahashi K, Lau YL: Mannose-binding lectin contributes to deleterious inflammatory response in pandemic H1N1 and avian H9N2 infection. J Infect Dis 2012, 205:44-53.

113. Bitko V, Barik S: Phenotypic silencing of cytoplasmic genes using sequence-specific double-stranded short interfering RNA and its application in the reverse genetics of wild type negative-strand RNA viruses. BMC Microbiol 2001, 1:34

114. Bitko V, Musiyenko A, Shulyayeva O, Barik S: Inhibition of respiratory viruses by nasally administered siRNA. Nat Med 2005, 11:50-55.

115. Ge Q, Filip L, Bai A, Nguyen T, Eisen HN, Chen J: Inhibition of influenza virus production in virus-infected mice by RNA interference. Proc Nat Acad Sci USA 2004, 101:8676-8681.

116. Tompkins SM, Lo CY, Tumpey TM, Epstein SL: Protection against lethal influenza virus challenge by RNA interference in vivo. Proc Natl Acad SCi USA 2004, 101:8682-8686.

117. Barik S: siRNA for influenza therapy. Viruses 2010, 2:1448-1457.

118. Zhou H, Jin M, Yu Z, Xu X, Peng Y, Wu H, Liu J, Liu H, Cao S, Chen H: Effective small interfering RNAs targeting matrix and nucleocapsid protein gene inhibit influenza A virus replication in cells and mice. Antiviral Res 2007, 76:186-193.

119. Zhou $K$, He H, Wu Y, Duan M: RNA interference of avian influenza virus H5N1 by inhibiting viral mRNA with siRNA expression plasmids. J Biotechnol 2008, 135:140-144.

120. Thakur N, Qureshi A, Kumar M: VIRsiRNAdb: a curated database of experimentally validated viral siRNA/shRNA. Nucleic Acids Res 2012, , 40 (Database): D230-236.
121. Raza A, Shareef H, Salim H, Khushal R, Bokhari H: Selection of predicted siRNA as potential antiviral therapeutic agent against influenza virus. Bioinformation 2011, 6:340-343.

122. ElHefnawi M, Alaidi O, Mohamed N, Kamar M, El-Azab I, Zada S, Siam R: Identification of novel conserved functional motifs across most influenza A viral strains. Virol J 2011, 8:44.

123. ElHefnawi M, Hassan $N$, Kamar M, Siam R, Remoli AL, El-Azab I, AlAidy O, Marsili G, Sgarbanti M: The design of optimal therapeutic small interfering RNA molecules targeting diverse strains of influenza A virus. Bioinformatics 2011, 27:3364-3370.

124. Sirnaomics homepage. [http://a216530356.oinsite.yh.mynet.cn/ _d272035470.htm]

125. Shaw ML: The host interactome of influenza virus presents new potential targets for antiviral drugs. Rev Med Virol 2011, 21:358-369.

126. MacArthur RD, Novak RM: Reviews of anti-infective agents: maraviroc: the first of a new class of antiretroviral agents. Clin Infect Dis 2008, 47:236-241.

127. Hao L, Sakurai A, Watanabe T, Sorensen E, Nidom CA, Newton MA, Ahlquist $P$, Kawaoka Y: Drosophila RNAi screen identifies host genes important for influenza virus replication. Nature 2008, 454:890-893.

128. Brass AL, Huang IC, Benita Y, John SP, Krishnan MN, Feeley EM, Ryan BJ, Weyer JL, van der Weyden L, Fikrig E, Adams DJ, Xavier RJ, Farzan M, Elledge SJ: The IFITM proteins mediate cellular resistance to influenza A H1N1 virus, West Nile virus, and dengue virus. Cell 2009, 139:1243-1254.

129. Shapira SD, Gat-Viks I, Shum BO, Dricot A, de Grace MM, Wu L, Gupta PB, Hao T, Silver SJ, Root DE, Hill DE, Regev A, Hacohen N: A physical and regulatory map of host influenza interactions reveals pathways in $\mathrm{H} 1 \mathrm{~N} 1$ infection. Cell 2009, 139:1255-1267.

130. Karlas A, Machuy N, Shin Y, Pleissner KP, Artarini A, Heuer D, Becker D, Khalil H, Ogilvie LA, Hess S, Mäurer AP, Müller E, Wolff T, Rudel T, Meyer TF: Genome-wide RNAi screen identifies human host factors crucial for influenza virus replication. Nature 2010, 463:818-822.

131. König R, Stertz S, Zhou Y, Inoue A, Hoffmann HH, Bhattacharyya S, Alamares JG, Tscherne DM, Ortigoza MB, Liang Y, Gao Q, Andrews SE, Bandyopadhyay S, De Jesus P, Tu BP, Pache L, Shih C, Orth A, Bonamy G, Miraglia L, Ideker T, García-Sastre A, Young JA, Palese P, Shaw ML, Chanda SK: Human host factors required for influenza virus replication. Nature 2010, 463:813-817.

132. Münk C, Sommer AF, König R: Systems-biology approaches to discover anti-viral effectors of the human innate immune response. Viruses 2011, 3:1112-1130.

133. Min JY, Subbarao K: Cellular targets for influenza drugs. Nat Biotechnol 2010, 28:239-240.

134. Medina RA, García-Sastre A: Influenza A viruses: new research developments. Nat Rev Microbiol 2011, 9:590-603.

135. Müller KH, Kakkola L, Nagaraj AS, Cheltsov AV, Anastasina M, Kainov DE: Emerging cellular targets for influenza antiviral agents. Trends Pharmacol Sci 2012, 33:89-99.

136. Tafforeau L, Chantier T, Pradezynski F, Pellet J, Mangeot PE, Vidalain PO, Andre P, Rabourdin-Combe C, Lotteau V: Generation and comprehensive analysis of an influenza virus polymerase cellular interaction network. J Virol 2011, 85:13010-13018.

137. Mata MA, Satterly N, Versteeg GA, Frantz D, Wei S, Williams N, Schmolke M, Peña-Llopis S, Brugarolas J, Forst CV, White MA, García-Sastre A, Roth MG, Fontoura BM: Chemical inhibition of RNA viruses reveals REDD1 as a host defense factor. Nat Chem Biol 2011, 7:712-719.

138. Kao RY, Yang D, Lau LS, Tsui WH, Hu L, Dai J, Chan MP, Chan CM, Wang P, Zheng BJ, Sun J, Huang JD, Madar J, Chen G, Chen H, Guan Y, Yuen KY: Identification of influenza A nucleoprotein as an antiviral target. Nat Biotechnol 2010, 28:600-605.

139. Balannik V, Wang J, Ohigashi Y, Jing X, Magavern E, Lamb RA, Degrado WF, Pinto LH: Design and pharmacological characterization of inhibitors of amantadine-resistant mutants of the M2 ion channel of influenza A virus. Biochemistry 2009, 48:11872-11882.

140. Jablonski JJ, Basu D, Engel DA, Geysen HM: Design, synthesis, and evaluation of novel small molecule inhibitors of the influenza virus protein NS1. Bioorg Med Chem 2012, 20:487-497.

141. Barik S, Bitko V: Prospects of RNA interference therapy in respiratory viral diseases: update 2006. Expert Opin Biol Ther 2006, 6:1151-1160.

142. Bitko V, Barik S: Intranasal antisense therapy: preclinical models with a clinical future? Curr Opin Mol Ther 2007, 9:119-125. 
143. Nguyen JT, Hoopes JD, Le MH, Smee DF, Patick AK, Faix DJ, Blair PJ, de Jong MD, Prichard MN, Went GT: Triple combination of amantadine, ribavirin, and oseltamivir is highly active and synergistic against drug resistant influenza virus strains in vitro. PLoS One 2010, 5:e9332.

Pre-publication history

The pre-publication history for this paper can be accessed here: http://www.biomedcentral.com/1741-7015/10/104/prepub

doi:10.1186/1741-7015-10-104

Cite this article as: Barik: New treatments for influenza. BMC Medicine 2012 10:104.

Submit your next manuscript to BioMed Central and take full advantage of:

- Convenient online submission

- Thorough peer review

- No space constraints or color figure charges

- Immediate publication on acceptance

- Inclusion in PubMed, CAS, Scopus and Google Scholar

- Research which is freely available for redistribution

Submit your manuscript at www.biomedcentral.com/submit 